удК 347.7

DOI https://doi.org/10.32837/apdp.v0i85.1875

O. I. Yenuc

\title{
БАЛАНС ІНТЕРЕСІВ СУБ'ЄКТІВ ПРАВА ІНТЕЛЕКТУАЛЬНОЇ ВЛАСНОСТІ КРІЗЬ ПРИЗМУ ПРИНЦИПІВ ПРОПОРЦІЙНОСТІ ТА СПРАВЕДЛИВОСТІ
}

Постановка проблеми. Пошук оптимальних форм балансу інтересів суб'єктів правовідносин $є$ зажди актуальним завданням для законодавця. А у сфері інтелектуальної власності в умовах гіпердинамічного розвитку інформаційного простору та технологій і поготів. Сучасні виклики вимагають гнучкого регулювання та оперативного реагування. Баланс інтересів також не є категорією сталою, а навпаки, динамічною. I співвідношення інтересів за цього балансу залежить від виду регульованих суспільних відносин, мети регулювання, конкретних обставин тощо.

Метою статті є аналіз проблеми досягнення балансу інтересів суб'єктів права інтелектуальної власності з огляду на принципи справедливості та пропорційності.

Аналіз останніх досліджень і публікацій. Пробема інтересів та їх співвідношення в різні часи досліджувалась у роботах I. Берестової, С. Братуся, I. Венедіктової, О. Вінник, О. Власової, В. Грибанова, Ю. Гамбарова, В. Горбунова, Ю. Євтушка, А. Кубко, О. Малька, С. Михайлова, О. Осипова, М. Першина, І. Покровського, В. Субочева, Ю. Тихомирова, О. Харитонової, Є. Харитонова, В. Чиркіна, Г. Шершеневича, Л. Явича. Аналіз проблемних аспектів понять «баланс», «справедливість» та «пропорційність» зустрічається в роботах Н. Блажівської, В. Вайпана, О. Отраднової, С. Погребняка, М. Преснякова, А. П'янкової, М. Савчина, С. Шевчука, М. Шугурова та інших.

Однією з метаідей, котрі лежать в основі більшості правових позицій Європейського суду із прав людини (далі ЄСПЛ), $є$ ідея балансу інтересів. Поняття «баланс інтересів» - не те ж саме, що просте примирення на тих чи інших умовах більшості і меншості, держави і особистості. Це поняття набагато змістовніше і глибше [1]. У ЄСПЛ неодноразово акцентувалась увага на порушенні саме «справедливого балансу між інтересами держави й заявника». У справі Акденіз проти Туреччини (№ 20877/10, 11 березня 2014 року) Суд підтвердив, що «коли йдеться про встановлення рівноваги між можливо суперечливими інтересами, які розглядаються, такими як «право на свободу отримання інформації» та «захистом авторських прав, «<...> органи державної влади мають особливо широкі межі розсуду». Заяву було подано до Суду звичайним користувачем інтернет-сайтів, котрі спеціалізуються на розповсюдженні музики. Він скаржився на те, що в червні 2009 року медіавідділ прокуратури дав розпорядження заблокувати доступ до веб-сайтів "myspace.com" та "last.fm" на підставі того, що ці сайти поширюють музичні твори з порушенням авторських прав. Скарга була визнана неприйнятною, оскільки як користувач цих сайтів, заявник був позбавлений лише одного засобу прослуховування музики серед багатьох інших. Суд не був переконаний, що ця справа порушує важливе питання загального інтересу. Беручи до уваги вищевикладене, заявник не міг 
заявити, що є «жертвою» порушення статті 10 Конвенції про захист прав людини й основоположних свобод (далі Конвенції) внаслідок оскаржуваного заходу [2]. Щодо підходу до захисту прав інтелектуальної власності загалом, показово, що підхід ЄСПЛ не відрізняється від його звичайного підходу: він розглядає й погоджує різні права та інтереси та оцінює необхідність і пропорційність утручання у здійснення певного права, захищеного Конвенцією [3, с. 66].

Дослідження практики ЄСПЛ дозволяє зробити висновок про те, що забезпечення балансу інтересів є однією із ключових цілей правосуддя. У кожній справі Суд перевіряє, чи було досягнуто справедливого балансу між інтересами, які зіткнулись у конкретній справі, виступаючи своєрідною вищою наднаціональною наглядовою інстанцією, перевіряючи правильність забезпечення балансу інтересів національними судами. У практиці ССПЛ напрацьовано три головні критерії, які необхідно оцінювати щодо відповідності втручання у право особи на мирне володіння своїм майном принципу правомірного втручання, сумісного з гарантіями ст. 1 Першого протоколу, а саме:

1) чи є втручання законним;

2) чи переслідує воно «суспільний інтерес» (public interest, general interest, general interest of the community);

3) чи є такий захід (утручання в право на мирне володіння майном) пропорційним визначеним цілям (must be a reasonable relationship of proportionality between the means employed and the aims pursued).

ЄСПЛ констатує порушення державою ст. 1 Першого протоколу, якщо хоча б одного критерію не буде дотримано. Принцип «пропорційності» (principle of proportionality), закріплений як загальний принцип у Договорі про заснування ЄС, вимагає співрозмірного обмеження прав і свобод людини для досягнення публічних цілей - органи влади, зокрема, не можуть покладати на громадян зобов'язання, котрі перевищують межі необхідності, які випливають із публічного інтересу, для досягнення цілей, що прагнуть досягнути за допомогою застосовуваної міри (або дій владних органів) [4]. Тобто, незважаючи на те, що країни-учасниці Конвенції наділені широкою свободою розсуду щодо визначення того, що потрібно розуміти під «суспільними інтересами» в умовах певного рівня національної економіки, політики й соціального захисту, ЄСПЛ у кожній ситуації досліджує, наскільки було дотримано державною владою справедливого балансу між інтересами суспільства й вимогами захисту приватних інтересів окремої особи (рішення Європейського суду у справах "Pressos Compania Naviera S.A. and others v. Belgium" [5], "Sporrong and Lonnroth v. Sweden" [6], "Chassagnou and others v. France" [7], "The Former King of Greece and others v. Greece" [8]) [9, c. 55].

Цікавою в контексті нашого дослідження є думка українського дослідника С. Погребняка про те, що захід чи дія є доречними для досягнення певної легітимної мети, не завжди свідчить про те, що вони є єдиноможливими. Якщо є інші, менш обтяжливі засоби, то в держави немає розумних причин використовувати засоби, які передбачають більше втручання: більш м’які засоби є оптимальними; вони краще відповідають інтересам громадян, водночас однаковою мірою відповідаючи інтересам держави. Ця вимога розглядається як юридичний еквівалент 
принципу оптимальності Парето. Вимога доречності та необхідності правових обмежень означає також, що розмір (обсяг) самого публічно-правового обмеження має бути диференційований залежно від конкретних обставин. Вимога найменш обтяжливих засобів нерідко пояснюється за допомогою популярного вислову, відповідно до якого не варто розколювати горіх кувалдою [10, с. 8].

По суті, набагато частіше трапляються випадки, в яких перевірка пропорційності зводиться до порівняння інтенсивності втручання з метою, яка переслідується. «Ваги, які використовуються Судом, здається, означають, що чим більше обмежується право або чим більш суттєвий аспект права, порушений обмеженням, тим більш суттєвими і переконливими повинні бути легітимні завдання, для виконання яких це обмеження накладається». Таким чином, послідовне й добросовісне застосування принципу пропорційності, перевірка актів на їх доречність та необхідність i, як наслідок, установлення справедливого балансу є важливою передумовою для забезпечення прав людини, утвердження верховенства права [10, с. 9].

У праві інтелектуальної власності за характеристики співвідношення приватних та суспільних інтересів часто вживається поняття «справедливий баланс». Очевидно, що тут ідеться не про просту рівновага, а саме про справедливе співвідношення. Як зазначає Д. Шестаков, «особливість інтелектуальної власності полягає в органічній єдності приватного та суспільного, і сутність цієї єдності - в мірі, у пропорціях» [11; 12 , с. 88]. Охорона приватних прав правовласників повинна бути збалансована таким чином, щоб навіть малозабезпечені особи мали можливість доступу до творів науки, літератури, мистецтва, інформації для задоволення своїх розумних потреб, котрі мають некомерційний характер. У той же час і автор (як творець) повинен отримувати певну вигоду, зокрема й матеріальну, від використання результатів своєї творчості, однак монополія автора теж повинна бути розумною. Тому справедливий баланс повинен забезпечувати відповідність розумних приватних інтересів авторів розумним потребам суспільства [12, с. 89].

Розглядаючи категорію «справедливість», В. Вайпан зазначає, що «у свідомості людей поняття справедливості служить для оцінки складних і суперечливих економічних, соціальних, юридичних, політичних і духовних процесів суспільного життя. Тому уявлення про справедливість $є$ певним індикатором поточного стану суспільства» [13, с. 49]. Справедливість, прагнення до її встановлення й підтримання як належного, як слушно зазначає А. Вязов, є однією з вічних ідей та бажань людства. Вона являє собою категорію суспільної свідомості й загальнолюдську цінність, тісно пов'язану з розумінням права [14, с. 3;15, с. 71]. На думку М. Преснякова, необхідно розрізняти справедливість як цінність і справедливість як регулятивний принцип. Із позиції загальної справедливості здійснюється морально-етична оцінка будь-якого соціального явища як справедливого або, навпаки, несправедливого шляхом співставлення його із системою цінностей в певному суспільстві в конкретний історичний період [16, с. 11]. Х. Харт зазначає, що правники з метою схвалення чи засудження правових норм чи їх застосування найчастіше оперують категоріями «справедливий» та «несправедливий» [17, с. 157]. На думку 3. Ромовської, закон - це мінімум справедливості. Решта має бути заповнена за допомогою дії принципу верховенства права. [15, с. 73] Аналогічна позиція висвітлена в Рі- 
шенні Конституційного Суду України у справі за конституційним поданням Верховного Суду України щодо відповідності Конституції України (конституційності) положень статті 69 Кримінального кодексу України (справа про призначення судом більш м’якого покарання): «Одним із проявів верховенства права є те, що право не обмежується лише законодавством як однією з його форм, а охоплює й інші соціальні регулятори, зокрема норми моралі, традиції, звичаї тощо, які легітимовані суспільством і зумовлені історично досягнутим культурним рівнем суспільства. Усі ці елементи права об’єднуються якістю, котра відповідає ідеології справедливості» [18]. Тому, коли йдеться про дотримання справедливого балансу інтересів суб'єктів правовідносин, величезне значення має діяльність судових органів, адже в судовій практиці вирішення питання про справедливість рішення зрештою залишається на розсуд судді й визначається за його внутрішнім переконанням.

Висновки. Вважаємо, що дотримання балансу інтересів суб'єктів права інтелектуальної власності забезпечується наділенням їх рівними можливостями для реалізації цих інтересів. Справедливий баланс інтересів суб’єктів права загалом та права інтелектуальної власності зокрема повинно забезпечувати законодавство. Однак через об'єктивні причини воно не може охопити своїм регулюванням усі відносини. Особливо у сфері інтелектуальної власності, де в умовах гіпердинамічного інформаційного суспільства баланс інтересів правовласників, суспільства та держави зможе забезпечити лише гнучке регулювання та судова практика. Саме тому ключову роль тут відіграють принципи, зокрема принцип справедливості (п. 6 ч. 1 ст. 3 ЦКУ) та принцип пропорційності (п. 6 ч. 3 ст. 2 ЦПКУ), зважаючи на які й повинні вирішуватись конфлікти інтересів.

\section{Jimepamypa}

1. Смирнов А. Социальное назначение уголовного судопроизводства: истина или умиротворение сторон? URL: https://justicemaker.ru/view-article.php?id=22\&art=5463.

2. Council of Europe/European Court of Human Rights. Information Note_on the Court's case-law. № 173. April 2014. URL:_https://hudoc.echr.coe.int/eng\#\{"itemid":["002-9493"]\}.

3. Пьянкова А. Принцип баланса интересов в практике Европейского Суда по правам человека. Евразийская адвокатура. № 4(23) 2016. С. 66-69.

4. У ВСУ підсумували рекомендації щодо захисту права власності. Газета Закон і Бізнес. URL: https://zib.com.ua/ua/print/120218-u_verhovnomu_sudi_pidsumuvali_rekomendacii_schodo_ zahistu_pr.html.

5. Справа "Pressos Campania Naviera S.A. and others v. Belgium" : рішення Європейського суду 3 прав людини від 3 липня 1997 p. URL: http://hudoc.echr.coe.int/eng?i=001-58056.

6. Справа "Sporrong and L nnroth v. Sweden" : рішення Європейського суду з прав людини від 23 вересня 1982 p. URL: http://hudoc.echr.coe.int/eng?i=001-57580.

7. Справ "Chassagnou and others v. France" : рішення Європейського суду з прав людини від 29 квітня 1999 p. URL: http://hudoc.echr.coe.int/eng?i=001-58288.

8. Справа "The Former King of Greece and others v. Greece" : рішення Європейського суду з прав людини від 23 листопада 2000 p. URL: http://hudoc.echr.coe.int/eng?i=001-59051.

9. Блажівська Н. Поняття «справедливий баланс» у практиці Європейського суду з прав людини. Актуальні проблеми правознавства. Випуск 1(13). 2018. С. 55-62.

10. Погребняк С. Тест на пропорційність. Юрист України. 2013. № 2. С. 5-10. URL: http://nbuv.gov.ua/UJRN/uy_2013_2_3.

11. Шестаков Д. Интеллектуальная собственность в Российской Федерации : дис. ... докт. юрид. наук. Москва : Российская академия государственной службы при Президенте Российской Федерации, 2000. 
12. Ситдикова Р. Справедливый баланс частных и общественных интересов как критерий эффективности правового регулирования. Илущественные отношения в Российской Федераиии. 2014. № 11(158). С. 87-94.

13. Вайпан В. Реализация принципа социальной справедливости в правовом регулировании предпринимательской деятельности. Проблемы реализации приниипов права в предпринилательской деятельности : монография / коллектив авторов МГУ имени М.В. Ломоносова, РАНХиГС при Президенте РФ. Москва : Юстицинформ, 2016. 340 с.

14. Вязов А. Принцип справедливости в современном российском праве и правоприменении (теоретико-правовое исследование) : дис. ... канд. юрид. наук : 12.00.01. Москва. 2001. 155 с.

15. Цюкало Ю. Принцип справедливості у цивільно-правовому аспекті. Науковий вісник Чернівецького університету. 2013. Випуск 644. Правознавство. С. 71-75.

16. Пресняков М. Конституционный принцип справедливости:_юридическая природа и нормативное содержание : автореф. дис. ... д. ю. н. Саратов, 2010. 46 с.

17. Харт Х. Концепція права. Скорочений переклад. Київ : Сфера, 1998. 231 с.

18. Рішення Конституційного Суду України у справі за конституційним поданням Верховного Суду України щодо відповідності_Конституції України (конституційності) положень статті 69 Кримінального кодексу України (справа про призначення судом більш м'якого покарання). Рішення Конституиійного суду України; Окрема думка від 02.11.2004 № 15-pn/2004. URL: https://zakon.rada.gov.ua/laws/show/v015p710-04.

\section{Анотація}

Чепис О. I. Баланс інтересів суб’єктів права інтелектуальної власності крізь призму принципів пропорційності та справедливості. - Стаття.

Справедливий баланс, зокрема у праві інтелектуальної власності, фактично є основною метою правового регулювання. А оскільки право (й законодавство) є відкритою, динамічною, такою, що розвивається, системою, то в ньому спонтанно або свідомо виникають моменти неузгодженості, або дисбалансу, які виявляються й тією чи іншою мірою усуваються. Водночас в умовах гіпердинамічного розвитку інформаційного простору та технологій регулювання має бути максимально гнучким. Зокрема, баланс інтересів суб'єктів права інтелектуальної власності може забезпечуватись наділенням ïx рівними можливостями для реалізації цих інтересів. Водночас статична рівновага інтересів однозначно не може бути оптимальною формою збалансування інтересів суб'єктів права інтелектуальної власності, оскільки за певних обставин об'єктивно необхідно встановлювати пріоритет одного інтересу над іншим. Також забезпечення балансу інтересів є однією із ключових завдань правосуддя. Тому одним зі способів установлення оптимального співвідношення інтересів у сфері інтелектуальної власності може слугувати звернення до судової практики, зокрема практики Європейського суду із прав людини, оскільки однією з метаідей, котрі лежать в основі більшості правових позицій ЄСПЛ є ідея балансу інтересів. Оскільки право не може охопити своїм регулюванням усі відносини (через кількісні, якісні та економічні причини), на допомогу приходять принципи, зокрема принцип справедливості та принцип пропорційності, зважаючи на які й повинні вирішуватись конфлікти інтересів. ЄСПЛ у кожній ситуації досліджує, наскільки було дотримано державною владою справедливий баланс між інтересами суспільства й вимогами захисту приватних інтересів окремої особи. Доречність та необхідність правових обмежень означає, що розмір (обсяг) самого публічно-правового обмеження має бути диференційований, залежно від конкретних обставин. Щодо підходу до захисту прав інтелектуальної власності загалом, показово, що підхід ЄСПЛ не відрізняється від його звичайного підходу: він розглядає й погоджує різні права та інтереси та оцінює необхідність і пропорційність утручання у здійснення певного права, захищеного Конвенцією.

Ключові слова: інтереси, баланс, рівновага, пропорційність, справедливість, інтелектуальна власність.

\section{Summary}

Chepys 0 . I. Balancing the interests of intellectual property rights through the prism of the principles of proportionality and fairness. - Article.

A fair balance, particularly in intellectual property law, is in fact the main purpose of legal regulation. And since the law (and legislation) is a developing, open, dynamic system, it spontaneously or consciously there are moments of inconsistency or imbalance, which are identified and to some extent eliminated. At the same time, in the conditions of hyperdynamic development of information space and control technol- 
ogies, it should be as flexible as possible. In particular, balance of interests of the subjects of intellectual property rights can be ensured by giving them equal opportunities to realize these interests. In this case, the static balance of interests clearly can not be the optimal form of balancing interests of the subjects of intellectual property rights, because in certain circumstances it is objectively necessary to establish the priority of one interest over another. Ensuring a balance of interests is also a key goal of justice. Therefore, one of the ways to establish the optimal balance of interests in the field of intellectual property can be recourse to case law, in particular the case law of the European Court of Human Rights, as one of the meta-ideas underlying most legal positions of the ECtHR is the idea of balance of interests. Since the law cannot cover all relations (for quantitative, qualitative and economic reasons), principles come to the rescue, in particular the principle of fairness and the principle of proportionality, in the light of which conflicts of interest must be resolved. In each situation, the ECtHR examines the extent to which the public authorities have struck a fair balance between interests of society and the requirements of protecting the private interests of the individual. The relevance and necessity of legal restrictions means that the size (scope) of the public law restriction itself should be differentiated depending on the specific circumstances. As for the approach to the protection of intellectual property rights in general, it is noteworthy that the approach of the ECtHR does not differ from its usual approach: it considers and reconciles different rights and interests and assesses the necessity and proportionality of interference with a right protected by the Convention.

Key words: interests, balance, proportionality, justice, intellectual property. 